Trivent Publishing

(C) The Authors, 2016

Available online at http://trivent-publishing.eu/

Series: Engineering and Industry

Volume: Watershed and River Basin Management

\title{
Water Framework Directive Catchment Planning A Case Study Apportioning Loads and Assessing Environmental Benefits of Programme of Measures
}

\author{
Bob Crabtree, ${ }^{1}$ Sarah Kelly, ${ }^{1}$ Hannah Green, ${ }^{2}$ \\ Graham Squibbs, ${ }^{3}$ Gordon Mitchell ${ }^{4}$ \\ ${ }^{1}$ WRc plc, Frankland Road, Swindon SN5 8YF, UK, bobcrabtree23@gmail.com, sarah.kelly@wrcplc.co.uk \\ ${ }^{2}$ Environment Agency, PO Box 519, South Preston, PR5 8GD, UK, Hannah.Green@environment- \\ agency.gov.uk \\ ${ }^{3}$ United Utilities PLC, Lingley Mere Business Park, Warrington, WA5 3LP, UK, Graham.Squibbs@uuplc.co.uk \\ ${ }^{4}$ The School of Geography, University of Leeds, Leeds, LS2 9JT, UK, g.mitchell@Leeds.ac.uk
}

\begin{abstract}
Complying with proposed Water Framework Directive (WFD) water quality standards for 'good ecological status' in England and Wales potentially requires a range of Programmes of Measures (PoMs) to control point and diffuse sources of pollution. There is an urgent need to define the benefits and costs of a range of potential PoMs. Water quality modelling can be used to understand where the greatest impact in a catchment can be achieved through 'end of pipe' and diffuse source reductions. This information can be used to guide cost-effective investment by private water companies and those with responsibilities for agricultural, industrial and urban diffuse inputs. In the UK, river water quality modelling with the Environment Agency SIMCAT model is regarded as the best current approach to support decision making for river water quality management and planning. The paper describes how a SIMCAT model has been used to conduct a trial WFD integrated catchment planning study for the River Ribble catchment in the North West of England. The model has been used to assess over 80 catchment planning scenarios. The results are being used support a national assessment of the cost-effectiveness of proposed PoMs.
\end{abstract}

\section{Keywords}

Ribble Catchment; SIMCAT; Water Frame Work Directive; Water Quality Modelling

This is an Open Access article distributed in accordance with the Creative Commons Attribution Non Commercial (CC-BYNC-ND 4.0) license, which permits others to copy or share the article, provided original work is properly cited and that this is not done for commercial purposes. Users may not remix, transform, or build upon the material and may not distribute the modified material (http://creativecommons.org/licenses/by-nc/4.0/) 


\section{Introduction}

Complying with the Water Framework Directive - 'the WFD' - (EC, 2002) water quality standards for 'good ecological status' in England and Wales potentially requires a range of Programmes of Measures (PoMs) to control point and diffuse sources of pollution. The regulated nature of the Water Industry, and a potential funding mechanism through the 5 year cycle of asset management plans (AMP), make it easier to target pollution from Water Industry continuous Wastewater Treatment Works (WwTWs) discharges and intermittent discharges from Combined Sewer Overflows (CSOs) and Stormtank discharges at WwTWs.

However, targeting point source discharges from the Water Industry may not represent the most efficient or cost effective way of reducing chemicals in water. There is an urgent need to quantify the water quality benefits of PoMs applied to Water Industry discharges at 'end of pipe' and other diffuse sources of pollution; for example, from urban runoff and agriculture. This will help to inform the current debate on the cost effectiveness of Water Industry and alternative PoMs. A key outcome will be a defence against Water Industry investment that does not contribute to a cost effective way for the UK to meet the WFD water quality standards and, therefore, not increasing customer bills unnecessarily. It may also help to defend against abortive investment in assets.

A recent United Kingdom Water Industry Research (UKWIR) study (WW17C205) 'Apportionment of Sources of Pollution Load and Benefits of Potential Measures' has used a catchment based water quality modelling approach as a 'test bed' to illustrate how different sources of pollution can be apportioned and how the impacts of different strategies for load reduction can be quantified in terms of water quality benefits. The study, based on the Ribble Catchment in the North West of England, was carried out by water and environmental consultants, WRc, with the support of the Environment Agency (EA), United Utilities (UU) and the University of Leeds.

The objectives of the study were to:

- Quantify pollution loads from point and diffuse inputs to the catchment from water company discharges, agriculture and urban runoff;

- Develop and calibrate a SIMCAT model of the Ribble catchment for BOD, Ammonia and Phosphate based on the identified pollution loads; and,

- Assess the water quality benefits that would arise from a range of individual and in-combination PoMs scenarios for point source and diffuse pollution control.

\section{Ribble Catchment Pilot Study}

In the UK, catchment water quality modelling using the EA's SIMCAT model (Crabtree et al.2005; Environment Agency, 2006) is regarded as the best current approach to support decision making for river water quality management and planning. SIMCAT is a mathematical model that describes the quality of river water throughout a catchment by using a Monte-Carlo simulation approach to predict the behaviour of the summary statistics of flow and water quality, such as the mean and a range of percentiles. It is a one dimensional, steady state model that can represent inputs from both pointsource discharges and diffuse inputs. SIMCAT offers a significant insight into catchment behaviour and, typically, SIMCAT models are based on the use of existing routine monitoring data for rivers and effluent quality from continuous discharges.

Recently, the EA has developed a national suite of GIS based SIMCAT models for all 11 River Basin Districts in England and Wales. These models are being used by the EA for strategic planning 
and to support the development of their WFD River Basin Management Plans. As part of this study the National SIMCAT model for the Ribble-Mersey River Basin District was used to create a SIMCAT model of the Ribble Catchment for a Pilot Study. The Ribble Catchment is located in the North West of England (Figure 1) and, above the freshwater limit at Preston, covers an area of $1540 \mathrm{~km}^{2}$ and has $659 \mathrm{~km}$ of river reaches that are required to achieve the proposed WFD water quality standards for 'good ecological status' (UKTAG, 2006) as shown in Figure 2.

There are 26 UU WwTWs with a population equivalent of over 250 in the catchment. The upper parts of the Ribble Catchment are largely rural and the population is concentrated in the Calder and Darwen subcatchments (Figure 1 and Figure 3). These provide the bulk of the effluent loads from the Burnley and Blackburn conurbations, respectively.

\section{Estimating Diffuse Pollution Loads}

Information for the spatial patterns of diffuse pollution from agriculture, urban runoff and wastewater intermittent discharges, derived from other modelling studies, were provided by the EA, the University of Leeds and UU, respectively. This approach is currently unique to the Ribble catchment model. In previous studies these proportions have been estimated during the model calibration phase making it difficult to correctly apportion the urban/agricultural load inputs across a catchment. The information, as annual loads, allowed a direct quantification of sources of Phosphate, BOD and Ammonia following model calibration.

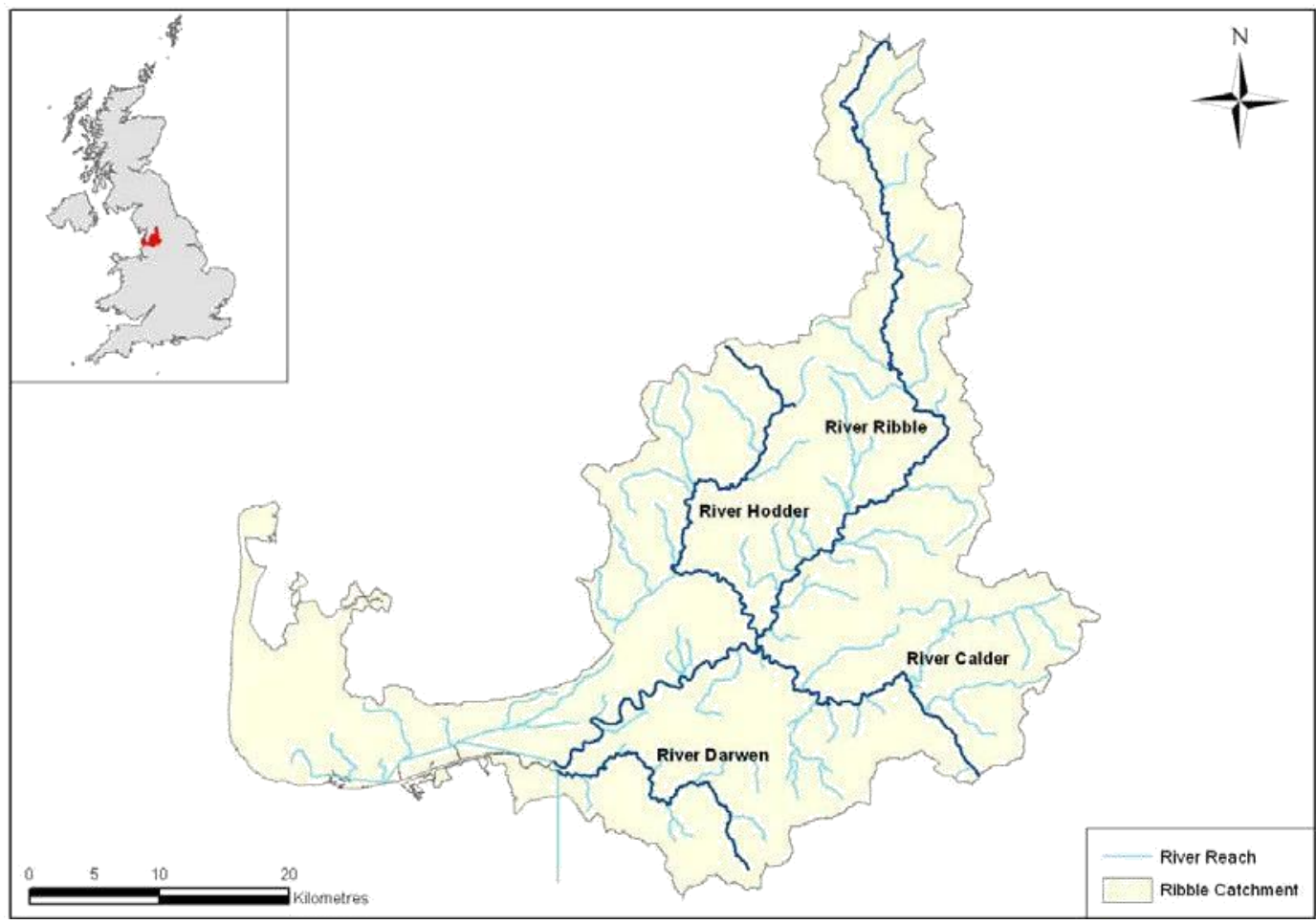

Fig. 1. River Ribble Catchment 


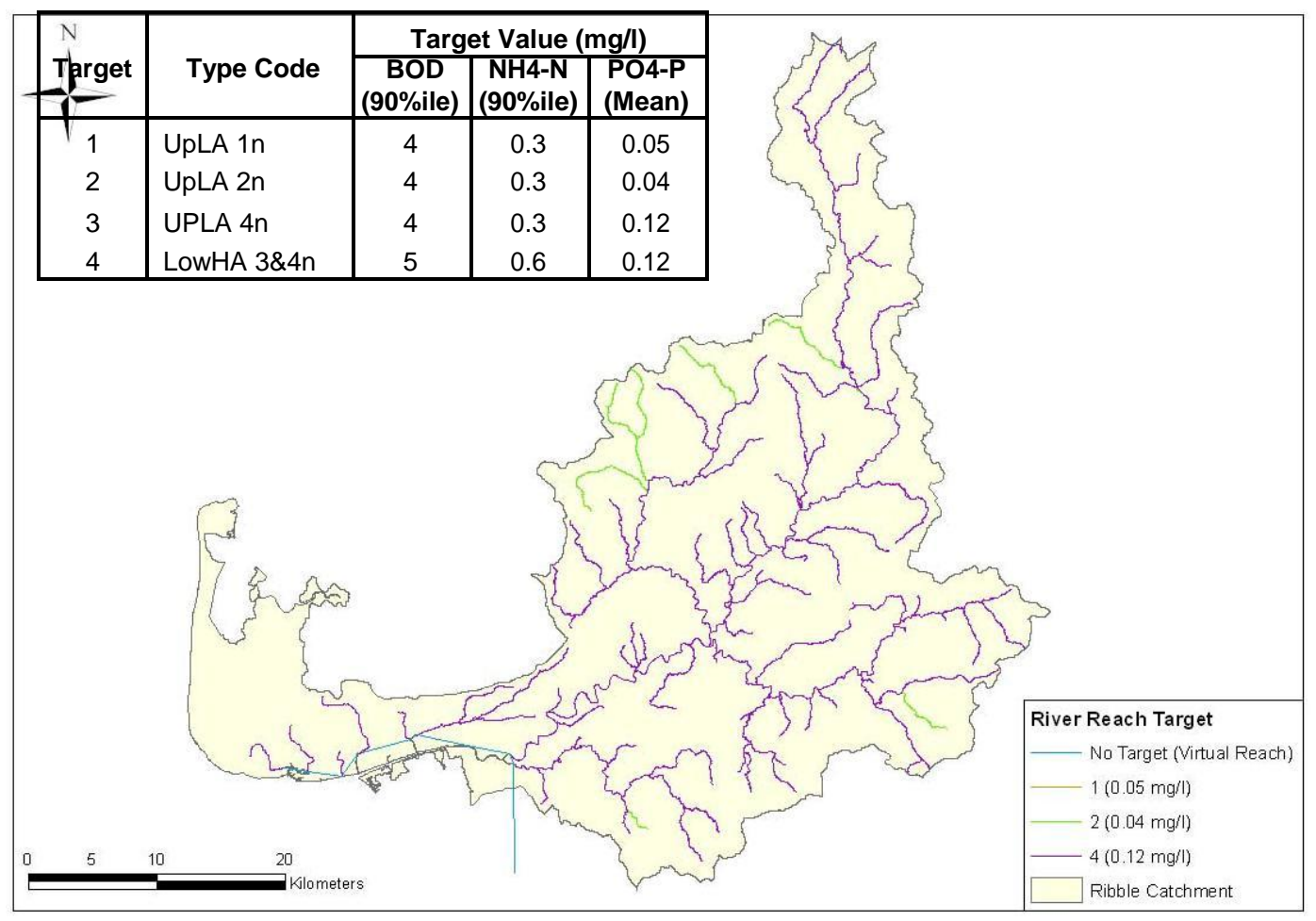

Fig. 2. Ribble Catchment Standards

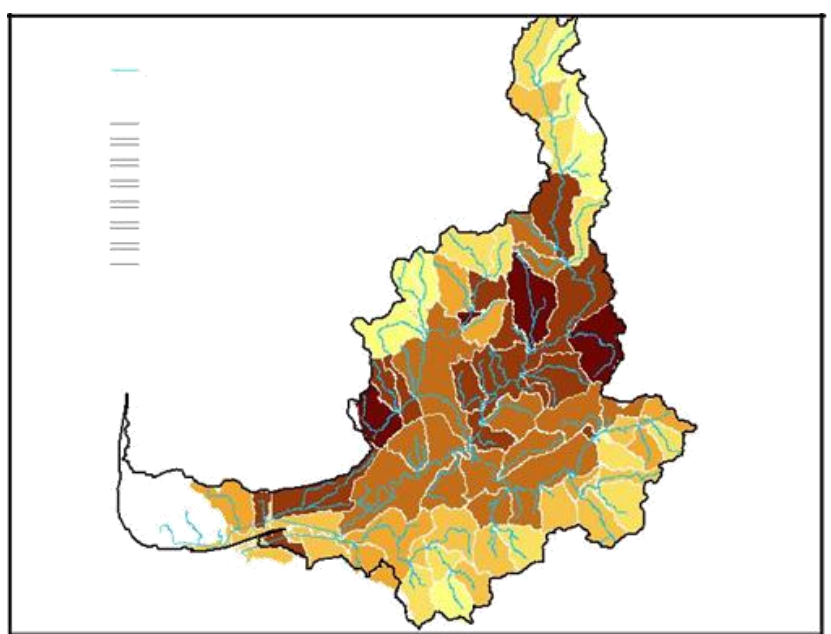

Fig. 3. Agricultural Diffuse Pollution Loads

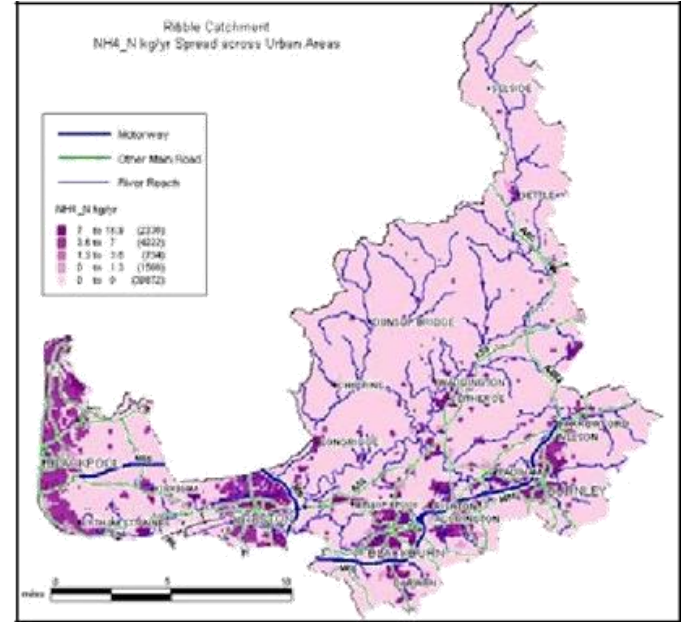

Fig. 4. Urban Runoff Diffuse Pollution Loads

\section{A. Agricultural Diffuse Pollution Loads}

Agricultural diffuse load data was supplied by the EA from the ADAS PSYCHIC model (Owens and Wood, 2003) for Phosphate. The PSYCHIC model was run at the catchment scale using national scale input datasets to derive predicted annual diffuse loadings for dissolved \& particulate Phosphate loss at a $1 \mathrm{~km}^{2}$ grid cell resolution. The predicted Phosphate grid cell values were summed within each water body and loads calculated per kilometer of reach within each water body for input to the Ribble SIMCAT model as shown in Figure 3. No agricultural diffuse load estimates were available for BOD 
and Ammonia for the Ribble Catchment and, instead, these loads were estimated during calibration by adding diffuse inputs on a reach by reach basis to account for unmodelled agricultural inputs.

\section{B. Urban Runoff and Urban Wastewater Intermittent Discharges}

Urban runoff for the Ribble catchment was estimated by the University of Leeds using a GIS model to quantify the pollution loads for BOD, Ammonia and Phosphate from urban non-point sources (Mitchell, 2005). A spatial resolution of $200 \times 200 \mathrm{~m}$ cells was used and roads were treated as separate linear objects (Figure 3). A summed load $(\mathrm{kg} / \mathrm{yr})$ for each of the individual model reaches was calculated from the 200x200m grid cells using a proximity analysis, as shown in Figure 4.

United Utilities provided information on the urban wastewater intermittent discharges within the urban wastewater networks in the Ribble catchment, as shown in Figure 5. Annual flow and loads from CSOs, WwTW Inlet Overflows and Storm Tank discharges were used to generate input data, on a reach by reach basis, for the Ribble SIMCAT model as shown in Figure 6. Annual flow volumes were derived directly from UU's existing wastewater system models, taking into account spill volume, spill duration and spill frequency. BOD and Ammonia loads were also taken directly from these models. Phosphate loadings were calculated from available data and comparison with BOD and Ammonia concentrations in spills from a UU wet weather sampling exercise.

To avoid any double counting between the urban wastewater and urban runoff loads, an analysis using UU's sewer record data was carried out to identify the separately drained areas and to calculate the total impermeable areas and separately drained impermeable areas in the Ribble catchment. The analysis found that there was a split of combined/separate sewered areas of the wastewater system in the proportion of $57 / 43 \%$. The urban runoff loads were apportioned accordingly with only $43 \%$ of the urban runoff load, representing the separately sewered areas, being included in the SIMCAT model.

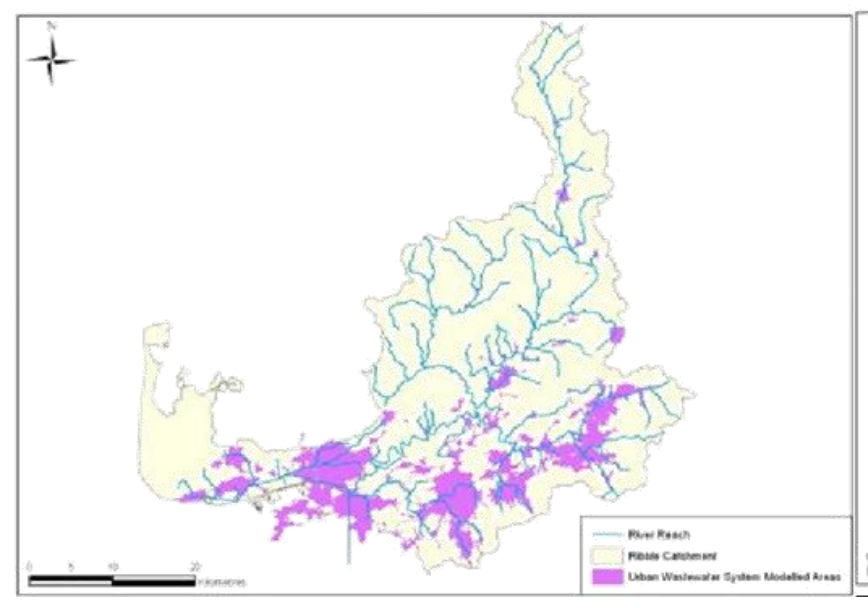

Fig. 5. Urban Wastewater Network Areas

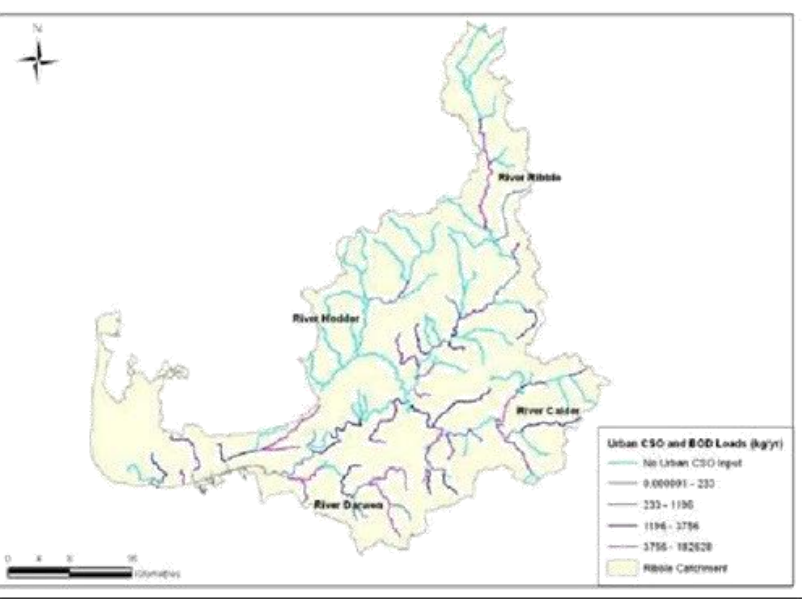

Fig. 6. Annual loads from Intermittent Discharges

\section{Model Calibration}

Calibration of a SIMCAT model is based on the manual calibration of flows, followed by pollutants, to meet an EA target manual calibration criteria for model predictions of the mean and 95\% ile to within \pm the Standard Deviation of the observed flow and quality data statistics at that location. The Ribble SIMCAT model was calibrated using a combination of observed data for river and WwTWs 
effluent flow and quality from EA and UUs' routine monitoring programmes for the period 20002004. During the calibration phase it was found that Phosphate was being overpredicted throughout the catchment. Consequently, the ADAS agricultural diffuse load inputs were reduced by varying amounts across the catchment to match the observed loads in the river. The results from the model calibration indicated that for Phosphate, WwTWs discharges produced $88 \%$ of the current catchment load estimated at $1505 \mathrm{~kg} / \mathrm{day}$, with agriculture and wastewater intermittent discharges plus urban runoff (urban diffuse inputs) producing around $9 \%$ and 3\% of the daily load, respectively as shown in Figure 7. For BOD and Ammonia, the WwTW discharges comprise a smaller proportion at $29 \%$ and $67 \%$ of the current catchment load estimates of $10414 \mathrm{~kg} /$ day and $1188 \mathrm{~kg} /$ day respectively (Figure 5). Agricultural diffuse load accounted for the largest proportion of BOD load to the Ribble Catchment.
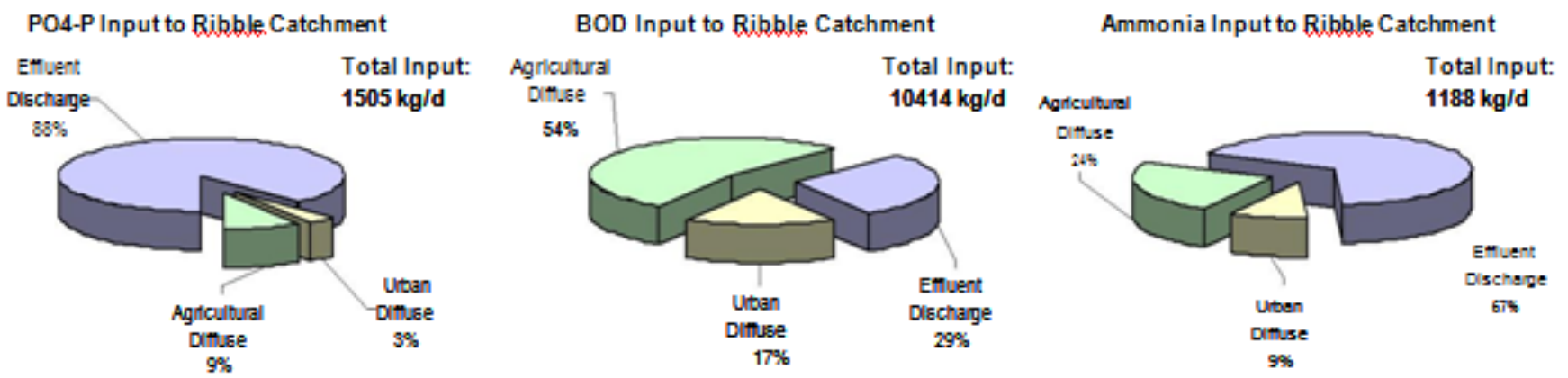

Fig. 7. Apportionment of Load Sources for Phosphate, BOD and Ammonia in the Ribble Catchment Following Model Calibration

\section{Programmes of Measures}

The Ribble SIMCAT model was used to examine a large number of PoMs scenarios to demonstrate the impact of reducing WwTWs loads alone and in combination with measures to reduce the diffuse inputs for Phosphate, BOD and Ammonia.

\section{A. Phosphate}

A large proportion of the rivers in the Ribble Catchment would be required to achieve a Phosphate standard of $0.12 \mathrm{mg} / \mathrm{l}$ as an annual mean under proposed WFD standards for 'good ecological status', as presented in Figure 2. A key Phosphate scenario for comparison with all others is the benefit of the pre-AMP4 investment in Phosphate removal consents at 6 WwTWs qualifying under the Urban Wastewater Treatment Directive (UWWTD). The model predicts that this will reduce the current Phosphate load from WwTWs by $761 \mathrm{~kg} /$ day - equivalent to a reduction in the WwTW load by $58 \%$ and an overall catchment reduction of $51 \%$. However, the length of river reaches predicted to pass the WFD standards would only increase by $0.5 \mathrm{~km}$.

Figure 8 illustrates the reach compliance in the Ribble Catchment following pre-2005 investment in Phosphate Removal, and the SIMCAT model predictions comparing the pre-Phosphate removal (blue line) and post-Phosphate removal (green line) water quality along the River Ribble against the WFD quality standard (red dashed line) of $0.12 \mathrm{mg} / \mathrm{l}$. The large reduction in Phosphate in the lower half of the Ribble is the result of Phosphate removal at WwTWs in the River Calder subcatchment. If all 
WwTWs in the catchment operated at current EA Policy Best Available Technology (BAT) Limit consents (based on an emission standard of 1mg/l for WwTW with PE > 1000 and $2 \mathrm{mg} / \mathrm{l}$ for WwTW with PE <1000) there would be a further reduction in WwTWs load of $263 \mathrm{~kg} /$ day compared to the load reduction produced by the AMP4 consents and a total of $502 \mathrm{~km}$ of river reaches passing the WFD standards - an increase of $3 \mathrm{~km}$. Further scenarios have examined water quality improvements that could be gained by other single and combined PoMs to reduce Phosphate loads from diffuse sources. The results indicate that achieving full compliance with the WFD Phosphate standard would require the daily load from all sources to be reduced to $82 \mathrm{~kg} /$ day - a reduction of the current consented total catchment load of $744 \mathrm{~kg} / \mathrm{d}$ from all sources by $90 \%$.
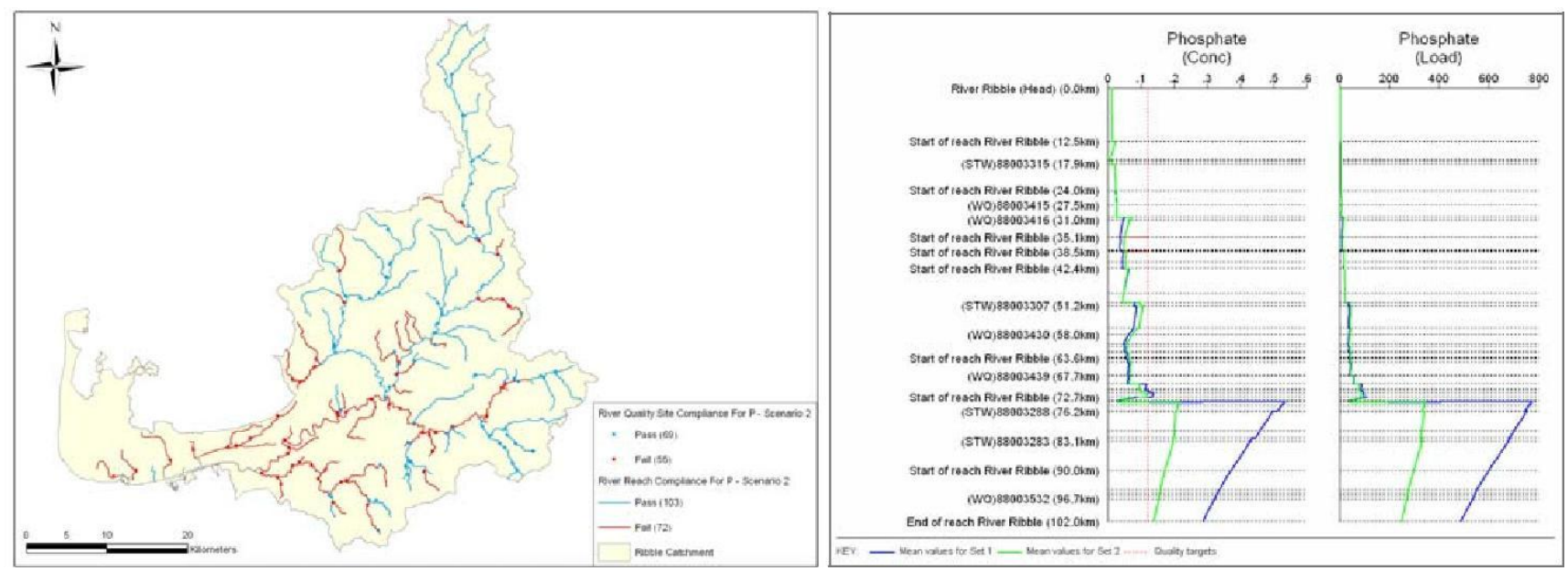

Fig. 8. Ribble Catchment Phosphate Current Consent Scenario - Overall Catchment Compliance (left) and SIMCAT Plot (Right) Showing the Predicted Impact of Current P Removal Consents

Table 1 provides a summary of the results from some of the key Phosphate scenarios.

Table 1. Phosphate Scenario Summary

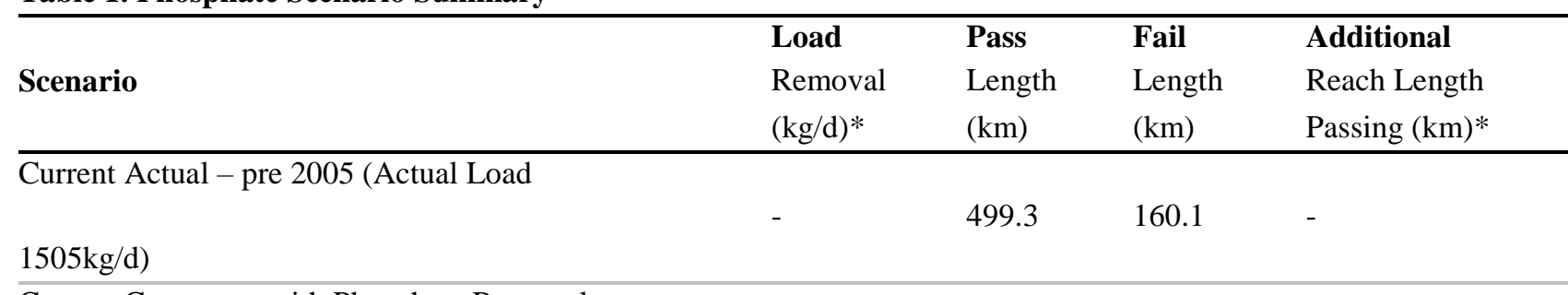

Current Consents - with Phosphate Removal

(Post-2005 Consented Load 744kg/d)

\begin{tabular}{llllll}
\hline WwTWs @ UWWTD Consents & 181 & 499.8 & 159.6 & 0.0 \\
\hline WwTWs @ EA BAT Limit Consents & 263 & 502.2 & 157.1 & 2.4 \\
\hline 100\% Reduction in Urban Runoff & 27 & 503.3 & 156.1 & 3.5 \\
\hline
\end{tabular}

Current Consents with Phosphate Removal

$\begin{array}{llll}89 & 499.9 & 159.5 & 0.1\end{array}$

$(25 \%)$ in Detergents

UWWTD Consents with Phosphate Removal

(25\%) in Detergents, 54\% Reduction in

Agriculture and 100\% Reduction in Urban Runoff 


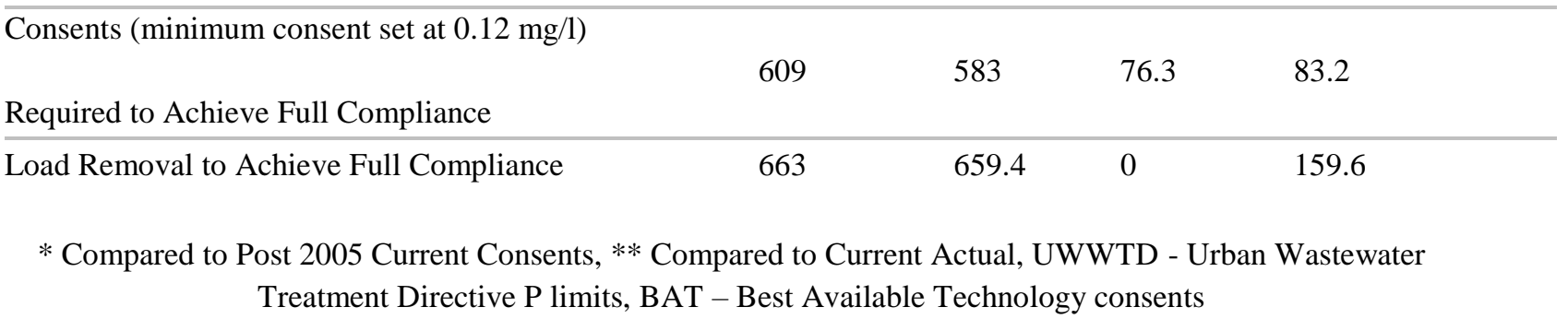

\section{B. BOD and Ammonia}

For BOD, current discharge consents should result in $581 \mathrm{~km}$ of the river passing the WFD BOD standards based on a reduction the current BOD load from WwTWs by $133 \mathrm{~kg} /$ day - equivalent to a reduction in the WwTWs load by $4 \%$ and an overall catchment reduction of just $1.3 \%$. If all WwTWs in the catchment operated at consents required to achieve the downstream water quality standard (with consents capped at the Best Available Technology (BAT) limit of $5 \mathrm{mg} / \mathrm{l}$ (95\%ile) and assuming a $54 \%$ reduction in the agricultural diffuse load and a $100 \%$ reduction in the urban runoff load) a 2730 $\mathrm{kg} / \mathrm{d}$ reduction in the WwTWs load compared to the current consented load would achieve compliance downstream of all WwTWs. This would result in a total of $651.2 \mathrm{~km}$ of river reaches passing the WFD standard - an increase of $70 \mathrm{~km}$ compared to the pre- AMP4 consents scenario. Where compliance fails to be achieved, for $8.1 \mathrm{~km}$ of reach length in the catchment, this indicates that further reductions in the agriculture and/or urban intermittent discharge load would be required to achieve the WFD water quality standards for all reaches.

For Ammonia, current discharge consents should result in $595 \mathrm{~km}$ of the river length passing the WFD Ammonia standards. The model predicts that this will actually increase the current Ammonia load from WwTWs by $43.3 \mathrm{~kg} / \mathrm{day}$, indicating that some of the WwTWs are currently operating at better than their consent limit. This would produce a small increase in the WwTWs load by $5.4 \%$ and an overall catchment increase of $3.6 \%$. The length of river reaches predicted to pass the WFD standards would decrease by $0.7 \mathrm{~km}$ as a result. If all WwTWs in the catchment operated at consents required to achieve the downstream water quality standard (with consents capped at the BAT limit of 1 $\mathrm{mg} / \mathrm{l}$ (95\%ile) and assuming a 54\% reduction in the agricultural diffuse load and a 100\% reduction in the urban runoff load) a $578 \mathrm{~kg} / \mathrm{d}$ reduction in the WwTWs load compared to the current consents loads would be required to achieve compliance downstream of the majority of the WwTWs. This would result in a total of $658.1 \mathrm{~km}$ of river reaches passing the WFD standard - an increase of $64 \mathrm{~km}$ compared to the current consent scenario. However, the WwTWs at Hyndburn (in the River Calder subcatchment) and Blackburn and Darwen (in the River Darwen subcatchment) would still fail to deliver the water quality standard downstream of their discharge, as consents tighter than the BAT limit to would be required to achieve full compliance.

\section{Conclusions}

In total, over 80 catchment management scenarios have been simulated using the Ribble catchment SIMCAT model. These have included examining alternative consenting and monitoring approaches plus a range of options for diffuse pollution reductions and Water Industry asset management options. 
The Ribble Pilot study has demonstrated that current information combined with a catchment modelling approach can be used to (1) apportion sources of pollution load across a catchment; and, (2) identify the water quality co- benefits of point source and diffuse pollution control measures to achieve compliance with WFD river quality standards. In particular, achieving WFD river quality standards for Phosphate is recognised as (and in this study has been proved to be), potentially, the greatest technical and financial challenge to meet the requirement of the WFD in the UK. For BOD and Ammonia, while compliance could just about be achieved by reducing WwTWs consent, this approach would not necessarily reflect a cost effective approach in relation to reductions from all sources, and particularly for BOD. In many respects, the issues facing the Ribble catchment are not atypical of other large catchments in England and Wales. The results from the study have helped to inform debate over the cost effectiveness of measures and have demonstrated the scale of some of the technical and economic challenges associated with the development and delivery of WFD River Basin Plans. In the future, a catchment modelling approach should ensure that catchments are provided with a satisfactory level of environmental protection at a realistic cost.

\section{References}

Crabtree B., Seward A., and Thompson L. (2005) A case study of regional catchment water quality modelling to identify pollution control requirements (2005) IWA $10^{\text {th }}$ International Specialised Conference on Watershed and River Basin Management - September 13-15, Calgary, Canada Environment Agency (2006) SIMCAT9.4 - A Guide and Reference for Users

EC (2002). Council Directive of 23 October 2002 establishing a Framework for Community Action in the Field of Water Policy (2000/60/EEC). Official Journal of the European Communities, No.

Mitchell G. (2005). Pollution Hazard from Urban Non-Point Sources: A GIS-Model to Support UK River Basin Planning, Journal of Environmental Management, 74, 1-9.

Owens P. and Wood, G. (2003). Phosphorus and sediment yield characterisation in catchments (PSYCHIC): Contribution from the National Soil Resources Institute (NSRI), Cranfield University. NSRI Report, National Soil Resources Institute, North Wyke.

UKTAG (2006). UK Environmental Standards and Conditions (Phase 1). Final Report (SR1 - 2006), UK Technical Advisory Group on the Water Framework Directive (www.wfduk.org).

\section{Acknowledgement}

This paper has been produced with the permission of the Directors of UKWIR, the Environment Agency, United Utilities, University of Leeds and WRc plc. The views expressed in the paper are those of the authors and not necessarily the views of these organizations. 